International Journal of Advanced Academic Research (Sciences, Technology and Engineering) | ISSN: 2488-9849 Vol. 6, Issue 8 (August, 2020) | www.ijaar.org

\title{
ENVIRONMENTAL EFFECTS OF COVID-19 IN KADUNA METROPOLIS, NIGERIA
}

\section{Simon Stephen Mshelia ${ }^{1}$, Ogar Paschal Unimke², Ogunkolu Ayodeji Bolade ${ }^{3}$ and Jediel Wabundani ${ }^{4}$}

1. Department of Geography, Federal University Gashua, Yobe State

2. Department of Geography, Nigerian Defence Academy, Kaduna

3. Department of Geography, Kogi State University, Anyigba

4. FRSC, National Headquarters, 4 Maputo St. Wuse, Zone 3, Abuja

Email: msheliasimon48@gmail.com

Tel: +2348035755461

\begin{abstract}
This study examined environmental effects of COVID-19 in Kaduna metropolis and was anchored on the concept of environmental sustainability and standards or guidelines on all kinds of wastes management put forward by Nigerian Environmental Standard and Regulation Agency (NESREA). Primary data were generated through administration of 180 structured and semi structured survey questionnaires in ten selected wards of the metropolis. Secondary data were obtained from desk review of other literatures. Descriptive statistics were employed for analyses of the data. Findings revealed that $86 \%$ agreed that the COVID-19 lockdown has temporarily resulted in the reduction of greenhouse gas emissions $\left(\mathrm{NO}_{2}\right)$ and improved air quality but have also led to generation of wastes and that these wastes are mostly left uncollected in the community as reported by $50.5 \%$ and $73.9 \%$ of the respondents respectively. The study also discovered that there was increase in the generation of medical infectious wastes by medical shops, chemists and clinics within residential areas as well as felling of trees for fuel purposes which increase climate change. The study recommends that wastes and medical infectious wastes should be properly stored in secured containers, treated and disposed in accordance to NESREA and environmental standards and educates the public on the environmental hazard of felling of trees in the communities.
\end{abstract}

Keywords: Environmental sustainability, Lockdown, Emission, Infectious waste, Climate change. 


\section{INTRODUCTION}

History has it that the Coronavirus disease known as COVID-19 outbreak emanated as an epidemic in the city of Wuhan, China in December 2019 and over a short time became a pandemic which is currently affecting the entire world without exception (Etukudoh et al, 2020). The developed world (USA, Italy, France) are most hit by the pandemic in terms of number of infections and causalities as well as the developing economy such as Brazil and India. At a point, the COVID-19 brought the world to her knees and is still causing great havoc in virtually all the sectors of the economy and on the environment (WHO, 2020a; Nassiri, 2020). Despite the high death rates in the developed world, the African people and the economy are worst affected. Nigeria is one of the countries in Africa that is presently witnessing tremendously upsurge of COVID-19 cases since $27^{\text {th }}$ February, 2020 when the index case was recorded in Lagos (African Women Unite against Destructive Resources Extraction, 2020; UN Inter Agency Network on Youth Development, 2020). It is an Italian citizen who was in Nigeria on business trip. Since, then the case keeps in number of confirmed cases and death. National Centre for Disease Control (NCDC) reported the cases in as at $1^{\text {st }}$ September, 2020 to be: Sample Tested 405,916; Confirmed Cases 54,247; Active Cases 11,214; Discharged Cases 42,010; Death 1,023 (NCDC, 2020).

The corona virus pandemic has influenced significant global crisis and the greatest effects are being experienced by the poor, local habitants, the public and civil servants especially in the private sectors all over the world. On African countries such as Nigeria, the COVID-19 pandemic is affecting many economic sectors, social environmental crises such as the unemployment, closure of markets and factories, hunger, increase in poverty levels, social violence such as increase rate of rape cases, civil unrest, climate change, environmental degradation, increase in generation of waste and land grabs among others (African Women Unite against Destructive Resources Extraction, 2020). These in most cases emanated as a result of lockdown imposed to curtail the spread of the virus. Furthermore, scientists, analysts and academics are linking COVID-19 to intrusion into extract of high demand resource as possible from a forested area and ecosystems as large companies pursue gain through large farming, cutting down of trees for timber and mining. These acts no doubt conducted for profit reasons and endanger the nature through the exploitation which lies at the heart of the pandemic of the COVID-19 (WHO, 2020b).

The outbreak in Nigeria has so far spread to all theStates and the Federal Capital Territory, Abuja. Record shows that Lagos has the highest cases of the Covid-19 and Kaduna a state in the Northwest rank $6^{\text {th }}$ in terms of confirmed cases with 2,141 as at $1^{\text {st }}$ September, 2020. Furthermore, it is estimated that $29 \%$ of the country's disease burden is linked to risk factors in the environment being the home of man. The environment is the sum total of all surroundings of living organisms; the aggregate of social, cultural, physical, chemical and biotic factors that influence the life of organisms, individuals and communities. It is very pertinent to note that the environment is very patient and absorbs both natural and anthropogenic activities but never forgives and gives back severely to the offender. Arguably, 
man through various anthropogenic activities has done more harm than good to the environment. These activities of man have resulted to numerous environmental problems that are bedevilling the world especially the developing economy. While the developed world has imbedded the concept of environmental sustainability, same cannot be said of the underdeveloped world such as Nigeria (WHO, 2020; Msheliaet al, 2020).

Aside from the health and the economic effects of Covid-19 such as the loss in both internal and external generation of revenue, closure of markets and businesses, loss of jobs, poverty and hunger among others; there are also environmental effects such as reduction in air pollution, generation of both solid and liquid wastes, land degradation (Bukky et al., 2020). Most of the economic and environment effects are as a result of the curfew, lockdown and quarantine enforced on the communities to curtail the spread of the virus (Muhammad et al. 2020). The most visible impacts or effects are economic related which has already attracted attention but there is little or no in depth study conducted on the environmental effects of the Convid-19 as a result of the lockdown, curfew or quarantine enforced in Kaduna State to curtail the infection or spread of the virus. Kaduna State was the first state in Nigeria that took the drastic step and enforced partial and then the total lockdown on the $25^{\text {th }}$ March, 2020 which resulted to both the environmental and socioeconomic effects. Of paramount concern to this study are the environmental effects.

The lockdown has led to the generation of enormous domestic wastewater and solid waste within the residential areas and along major streets. Wastewaters in form of sewages are seen in gutters, drainage channels, along street and open spaces. This is possible because only essential and skeletal services are being rendered and coupled with the majority of families are confined at home, the resultant effects are eating and generation of different kinds of wastes. Similarly, hospitals, clinics and medical stores during this period of the pandemic have witnessed increase in the number of patients and this has resulted to the increase in the medical waste known as infectious waste (Oruonye and Ahmed, 2020). People that work at hospitals and medical related institutions are encouraged to wear personal protective equipment (PPE) such as disposable hand gloves, gowns, aprons, surgical masks or N95 face or nose masks and glass-like face protectors. Others are respirators, face shields and other materials used to treat patients. The issue here which form the problem of the study is the management of these enormous medical infectious wastes and the domestic wastes generated during the period of the lockdown. This is because some hospitals, clinic, medical laboratories and stores are careless with how these wastes are managed in this critical period of the Covid-19 pandemic (Oruonye and Ahmed, 2020; Roland, 2020; Cutler, 2020). Some of the wastes are disposed at dumpsites or burnt without compliance to the rules stipulated by the National Environmental Standard and Regulation Enforcement Agency (NESREA, 2017). In the same vein during the lockdown, many less privileged families who cannot afford gas or kerosene as cooking fuel have been cutting down trees in the communities for fuel purposes. It is on the basis of these that the study examined the environmental effects of COVID-19 in Kaduna Metropolis. 


\section{CONCEPTUAL CLARIFICATIONS}

The study keyed into the concept of environmental sustainability and standards or guidelines of the Nigerian Environmental Standard and Regulation Enforcement Agency (NESREA).

\section{Nigerian Environmental Standard and Regulation Enforcement Agency (NESREA)}

NESREA was established by the NESREA establishment Act 2007, Law of the Federation of Nigeria (LFN) and NESREA Act 2018 as amended, is an environmental agency under the supervision of the Federal Ministry of Environment in Nigeria which is saddled with the responsibility of enforcing all environmental laws, regulations, standards, policies and guidelines in Nigeria (NESREA, 2017). It also oversees the prohibition processes as well as the use of equipment or technology that undermine environmental quality. NESREA also ensures compliance with the provisions of international environmental treaties, agreements, protocols and conventions to which Nigeria is a signatory (NESREA, 2020). NESREA provided guidelines for handling infectious waste within the context of coronavirus (covid19) in environmental matters and other wastes. Notable of these are: that every container or dustbin that contains infectious waste must be properly closed; all infectious wastes must be sterilized, treated or disinfected before disposal. Similarly, all health care facilities used for the treatment of COVID-19 patients or other infectious related diseases must be provided with well covered receptacles for putting the waste materials and properly treated or disinfected. It also requires health workers to be well kitted and completely in their PPE when handling infectious disease patients. These guidelines are applicable to management of wastes at residential areas, industries and all types of hospitals, clinics and medical facilities or stores.

\section{The Concept of Environmental Sustainability}

Goodland (1995) puts forth a definition of environmental sustainability as "the maintenance of natural capital and also as a concept that is connected to both social and economic sustainability". Environmental Sustainability is also referred to as the maintenance of universal life support systems, which avail goods and services to human community. These includes the source capacities of ecosystems which provide material inputs such as food, water, air, and energy; sink capacities on the other hand assimilate outputs and wastes of various kind (Goodland, 1995). On this basis environmental sustainability can likewise be viewed as responsible interaction with the environment to prevents depletion or degradation of all kinds of resources and provide avenue for long-term environmental quality. It is also pertinent to note that environmental sustainability is built on three pillars which formed the foundation of what the concept represents. They are economy, society, and the environment. The primary point of the concept based on the pillars is that there should be two or double irreducible (dualistic) relationship between human beings and the ecosystem they inhabit where there exist a union that ensure potable clean water, unpolluted air, good and productive land foundational to a responsible socioeconomic system are provided (Mebratu, 1998). The concept therefore brings to light that man should not take the COVID-19 Pandemic lockdown 
Journal DOI: 10.46654/ij.24889849

as excuse to exploit the environment through indiscriminate disposal of wastes and felling of trees but imbed the concept for better environment quality for him and the future generations.

\section{MATERIALS AND METHODS}

\section{Study Area}

The study was carried out in Kaduna metropolis which comprises of Kaduna north, Kaduna South, Igabi and Chikun Local Government Areas Figure 1. The investigation was conducted in Kaduna metropolis which is located between Latitudes $10^{\circ} 20^{\prime} \mathrm{N}$ and $10^{\circ} 37^{\prime} \mathrm{N}$ of the Equator and Longitudes $7^{\circ} 22^{\prime} \mathrm{E}$ and $7^{\circ} 31^{\prime} \mathrm{E}$ of the Greenwich meridian. The state is bounded to the South-West by Abuja and Niger State, Katsina, and Zamfara at the North-West, Kano and Bauchi share boundaries with Kaduna at the North-East while Plateau and Nasarawa are bounded at the South-East (Mshelia et al, 2020). The metropolis covers an area of about $260 \mathrm{Km}^{2}$.

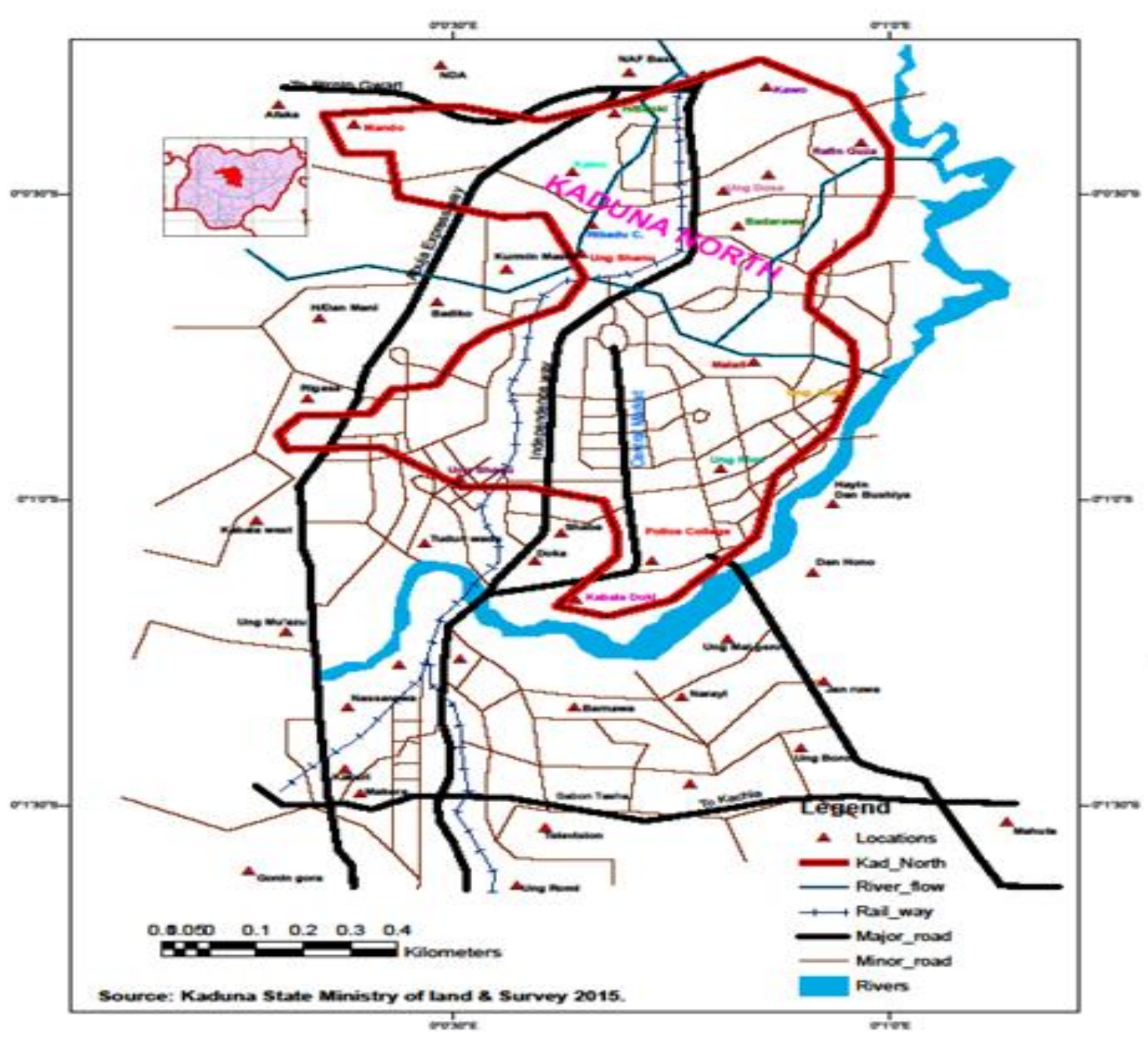

Figure 1: Map of Kaduna Metropolis

Source: Adapted in Tadama (2016) 


\section{Climate and Weather}

The climate of Kaduna State is tropical in nature with divergent seasonal trends and variability that moves back and forth or flutter between cool to hot dry and from humid to wet, with average annual temperature of $25.2^{\circ} \mathrm{C}$ and sometimes it reaches $29-30^{\circ} \mathrm{C}$ in March - June. Rainfall durations swing between 150days to 190days amounting an annual rainfall of between $1500 \mathrm{~mm}$ to $2000 \mathrm{~mm}$. The relative humidity falls between $20 \%$ and $30 \%$ in January and rises to between $60 \%$ and as high as $80 \%$ in July (Mshelia et al., 2020; Al-amin and Dadan-Garba, 2014).

\section{Methods of Data Collection}

Ten wards in Kaduna metropolis were randomly selected. A sample size of 180 was also randomly, purposefully and systematically selected and administered questionnaires. The study employed direct observations (reconnaissance survey) at the preliminary level of the study to get first-hand information on the effects of CONVID-19 on the environment in Kaduna Metropolis. Primary data were generated from structured, semi structured and field interview questions in actual form where follow up questions were asked to further elucidate the questions and responses during the course of the interview (Mshelia et al., 2020). Similarly, five hospitals and ten medical stores (chemists) were randomly selected, visited and interviewed the staff. The secondary data were obtained from desk review of relevant literatures, documents or materials such as journals, textbooks, the proceedings of seminars and other research works. Photographs of waste generated were taken at different locations. Descriptive statistics was employed and analyzed data in tables and charts in simple arithmetic mean and frequency. Similarly, Likert Rating Scale of Agree (A), Neutral (N) and Disagree (D) was adapted and used where necessary.

\section{RESULT AND DISCUSSION}

This section presents data obtained from the field on the cutting down of trees for road constructions in Kaduna metropolis. Observations and opinions of different groups or individuals were presented using descriptive statistics in form of tables, charts and figures.

\section{Socio-Demographic and Economic Characteristics of Respondents}

Demographic variables as age, educational status, occupations and family size have considerable impacts on the perception of self and the environment especially on effects of waste generation and pollution in urban centres (Butu and Mshelia, 2017). The study therefore, considered the demographic characteristics of the respondents who are mostly civil servants and labourers such as mason, bricklayers and carpenters among others. The civil/public servants were purposefully selected because of the belief that their level of education and exposure will aid in obtaining nearly perfect data and of a truth it did. Of the 180 respondents administered questionnaires and interviewed, $60 \%$ and $40 \%$ are males and females as on Table 4.1. Majority of the respondents of $60.6 \%$ were within the age group 41 - 50 because they were assumed to be experienced and mature enough to make good judgment on the effects of COVID-19 on the environment in Kaduna Metropolis. Preference 
was also accorded to those with tertiary education where $53.9 \%$ of the respondents and civil/public servants $38.9 \%$ administered for better feedback. Similarly, Mustapha (2011) is of the view that population such as family size contributes significantly to the volume of waste being generated in cities. In this regard, the highest percentage of $47 \%$ of the respondents falls within the family size bracket of $16-20$.

Table 4.1: Socio-Economic Characteristics of the Respondents

\begin{tabular}{|c|c|c|}
\hline Characteristics & Frequency & Percentage \\
\hline \multicolumn{3}{|l|}{ Age } \\
\hline $21-30$ & 16 & 8.9 \\
\hline $31-40$ & 21 & 11.7 \\
\hline $41-50$ & 109 & 60.6 \\
\hline $51-60$ & 24 & 13.3 \\
\hline 61 and above & 10 & 5.6 \\
\hline \multicolumn{3}{|l|}{ Gender } \\
\hline Male & 108 & 60 \\
\hline Female & 72 & 40 \\
\hline \multicolumn{3}{|l|}{ Educational Status } \\
\hline No Formal Education & 15 & 8.3 \\
\hline Primary Education & 23 & 12.7 \\
\hline Secondary Education & 45 & 25 \\
\hline Tertiary Education & 97 & 53.9 \\
\hline \multicolumn{3}{|l|}{ Occupation } \\
\hline Traders/Business men/women & 52 & 28.9 \\
\hline Civil/Public Servants & 70 & 38.9 \\
\hline Labourers (Mason, Carpenters) & 45 & 25 \\
\hline House Wives & 06 & 3.3 \\
\hline Others & 07 & 3.9 \\
\hline \multicolumn{3}{|l|}{ Family Size } \\
\hline $1-5$ & 15 & 8.3 \\
\hline $6-10$ & 20 & 11.1 \\
\hline $11-15$ & 45 & 25 \\
\hline $16-20$ & 85 & 47 \\
\hline 21 and above & 15 & 8.3 \\
\hline
\end{tabular}

Source: Field Survey, (2020)

\section{COVID-19 Lockdown has aided the reduction of Air Pollution}

The study sought the opinions of 180 residents in the metropolis through the administered questionnaires and found out that $86 \%$ agreed that the lockdown has greatly reduced air pollution and improved greenhouse gas. Only 6\% disagreed while $8 \%$ reported neutral as shown on Figure4.1. This indicates that the lockdown effect which restricted vehicular movement and operations of heavy duty machines in the metropolis has contributed significantly to the reduction of air pollution which consequently has reduced the rate of impacts of heart or cardiac related diseases. Similarly, assessment of pollution during 
COVID-19 by National Aeronautics and Space Administration (NASA, 2020) and European Space Agency (ESA, 2020) showed that the reduced transport activities have led to limited consumption of energy and lesser oil demand. These changes have exercised an important impact on the environmental quality. The reported fresh evidence indicates that during the lockdown period the environmental quality improved and the emission of $\mathrm{NO}_{2}$ reduced to $30 \%$ in Europe which is also applicable to Africa. This also means that COVID-19 has temporarily resulted in the reduction of greenhouse gas emissions and improved air quality.

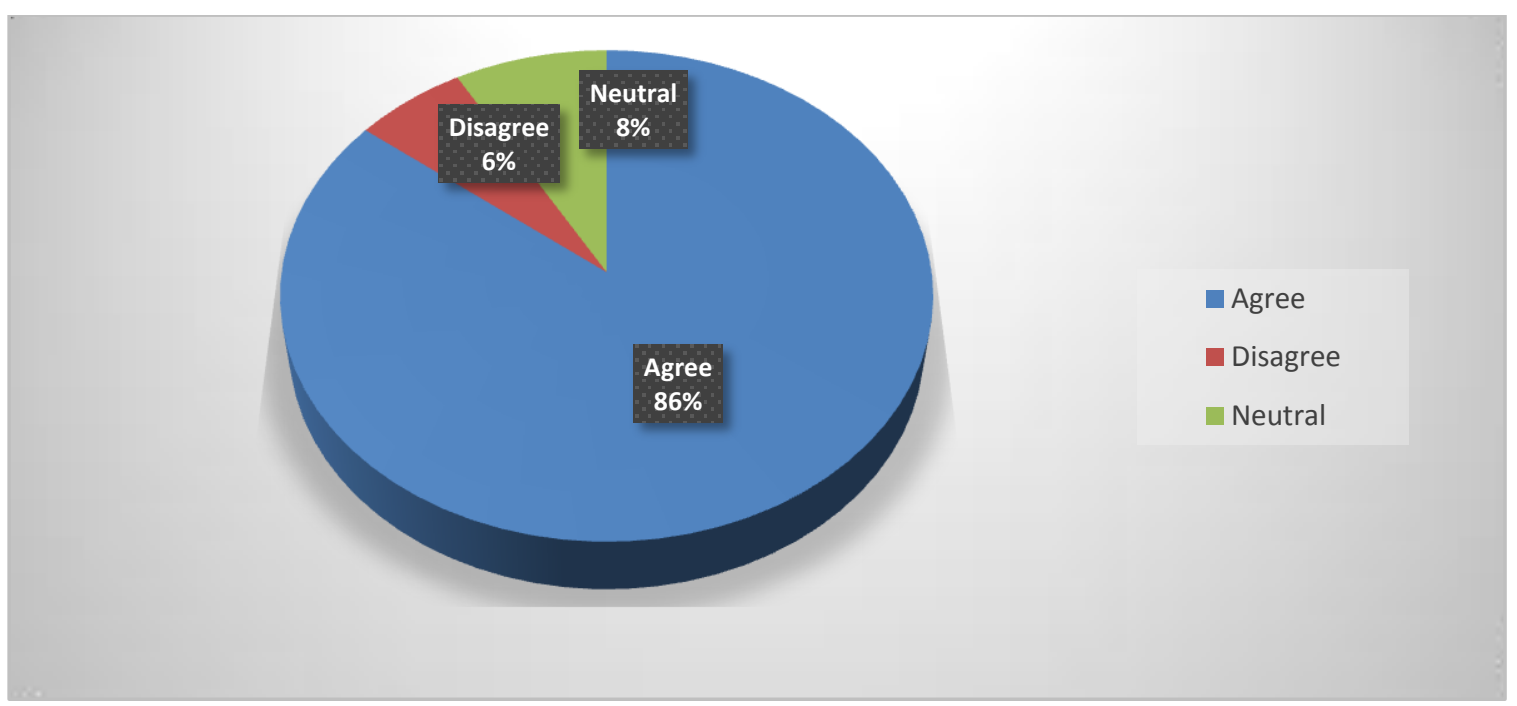

Figure 4.1: COVID-19 Lockdown aided the reductionof air pollution Source: Field Survey, (2020)

\section{Effects of COVD-19 Lockdown on Households and the Environment}

The views of 180 respondents in the metropolis on the effectof COVID-19 lockdown on households and environment as shown on Table 4.2 which reveals that $26.7 \%$ are of the opinion that it has led to inadequate fund to meet the basic needs, $11.1 \%$ indicates that they get bored while majority of the respondents of $50.5 \%$ opined that it has significantly contributed to generation of wastes especially wastewater.Further pre-formulated questions revealed that those with large families sit at home, eat food, generate wastes and frequently visit the toilet to excrete. The children also play and lither papers and all sort of wastes. Unity and disharmony at homes as a result of the lockdown recorded $6.7 \%$ while others reported only $3.9 \%$. This reveals that although, the other indicated variables also have effects but the wastes generation is the most noticeable effect on household and the environment at large in the metropolis during the lockdown. 
Table 4.2: Effects of COVID-19 Lockdown on Households

\begin{tabular}{l|l|l}
\hline Variables & Frequency $(\mathrm{n}=180)$ & $\%$ \\
\hline Inadequate Fund & 48 & 26.7 \\
Staying indoor is boring & 20 & 11.1 \\
Waste generation & 91 & 50.5 \\
Unity or disharmony in the family & 12 & 6.7 \\
Others & 07 & 3.9 \\
\hline
\end{tabular}

Source: Field Survey $(2020$

\section{Rate or Status of Waste Collections in the Metropolis during the Lockdown}

Figure 4.2 shows the responses of the 180 people administered questionnaires on the rate or status of waste collections in the metropolis during the lockdown. Collection on daily basis recorded $2.8 \%$ perhaps the respondents reside close to the main roads but, even at that the Kaduna Environmental Protection Agency (KEPA) does no operate on weekend days (Saturday and Sunday). Collection on weekly reported $9.4 \%$, monthly recorded $13.9 \%$ while majority of the respondents of $51.1 \%$ are of the opinion that wastes at their areas are collected occasionally and $22.8 \%$ reported that wastes are never collected during the lockdown. The collective responses of occasionally and never represents $73.9 \%$ by large speaks on the reason of enormous wastes uncollected in the environment. Further question to elucidate the collection occasionally and indicated that sometimes it take a month or more than before KEPA visit the main roads on their areas. The private waste agencies that use to come either on weekly basis hardly come around during the lockdown. This leaves the environment with overflowing waste bins and wastes of different kinds in the environment as shown on Plates 1 and 2.

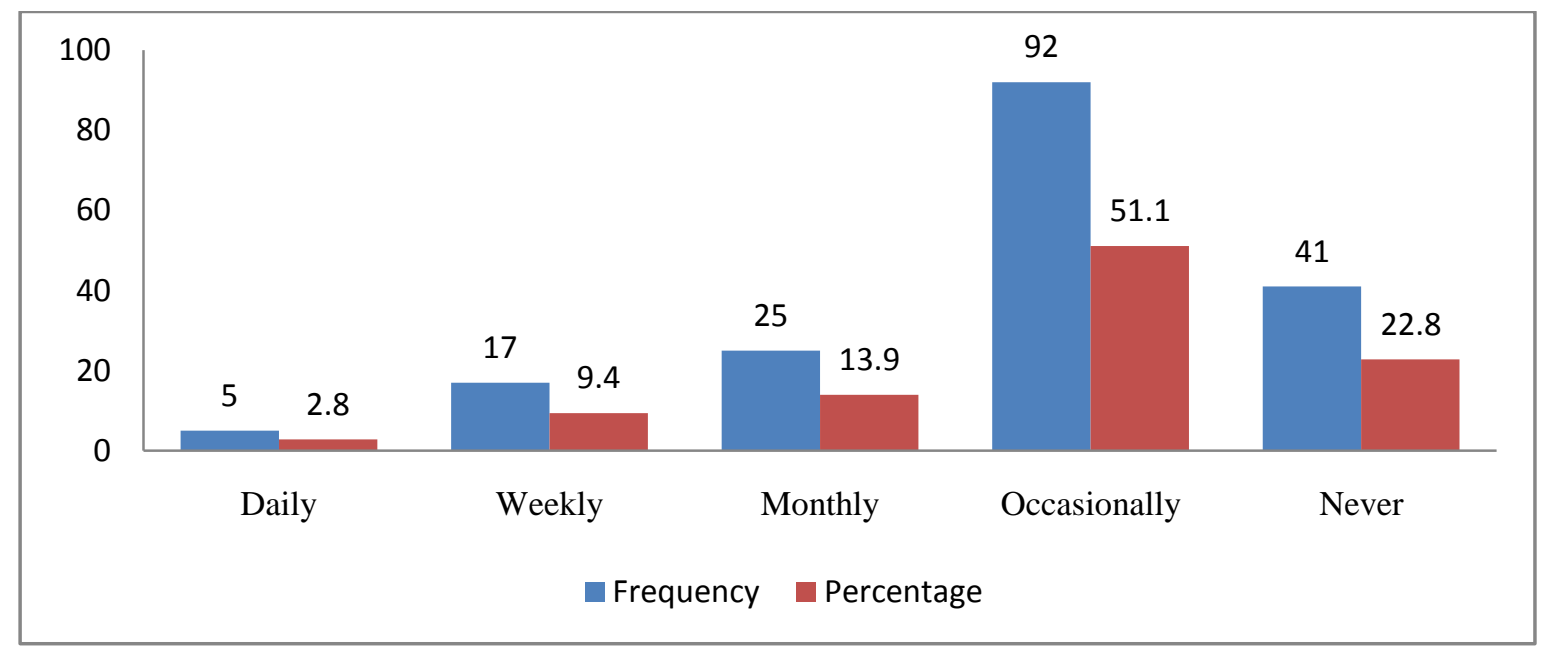

Figure 4.2: Rate or Status of Waste Collections in the Metropolis during the Lockdown Source: Field Study (2020) 


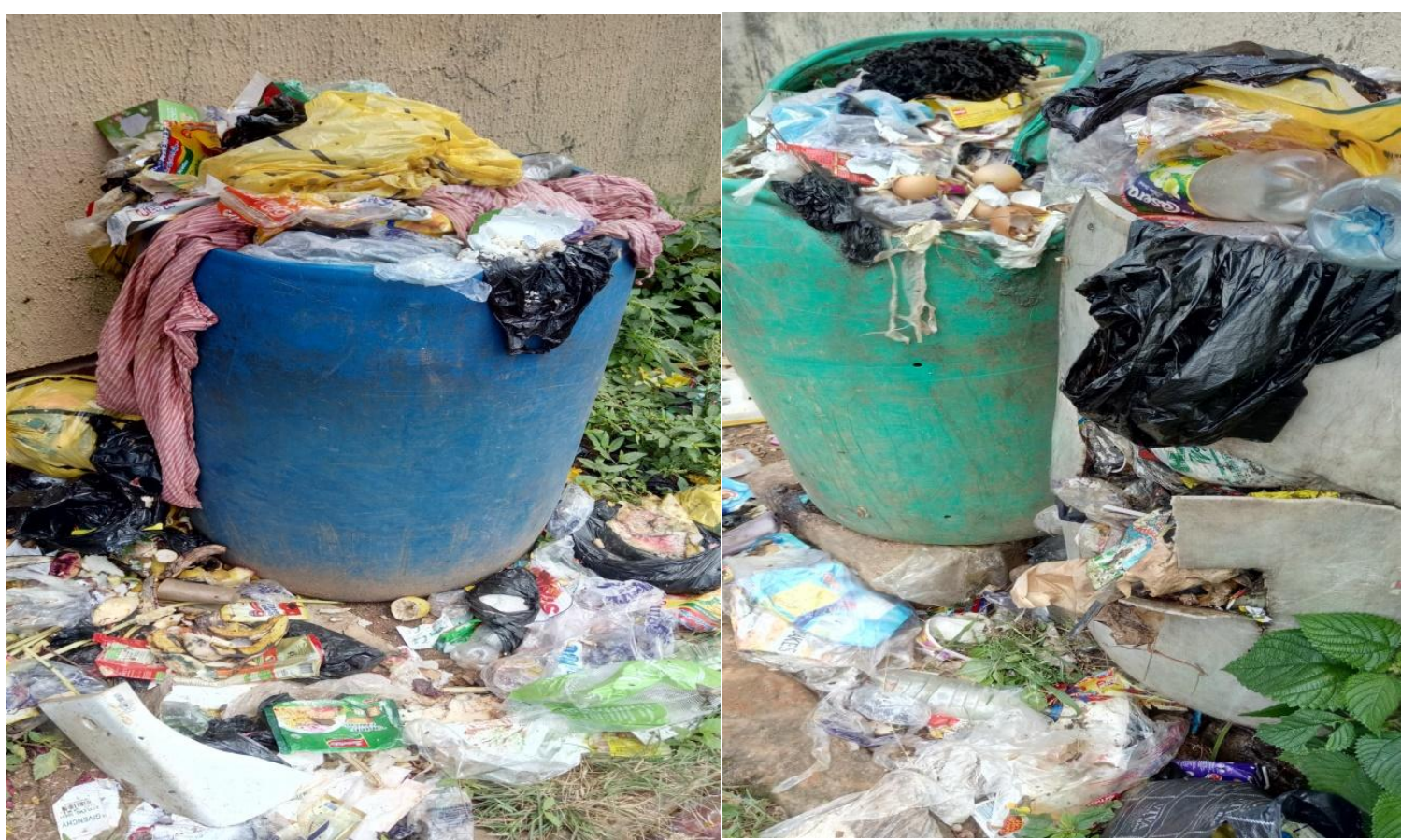

Plate 1: Uncollected Wastes

Plate 2: Overflowing Waste Bin

\section{Medical Infectious Waste Generated from Health Service Institutions}

The study investigated the waste generated from hospitals, clinics, patents medical stores, medical laboratories and revealed that during the COVID-19 lockdown people resorted to any medical facility near their residence. Interview with the Chemist Operators and other staff of medical centres showed that they attend to patients with any kind of ailments since people are afraid to visit major hospitals and also to avoid the molestations and extortions by the security agencies in the course of going to hospital. Further interview with the medical store owners and small outlet clinics workers revealed that they do not treat or sterilized the waste generated from the treatment of patients. The wastes aremostly unsecured as shown on Plate 3 and disposed at waste collection centres or at any illegal dumpsites within the environment. This is contrary to the regulations of NESREA on treatment and handling of infectious medical wastes as also observed by Oruonye and Ahmed (2020). 


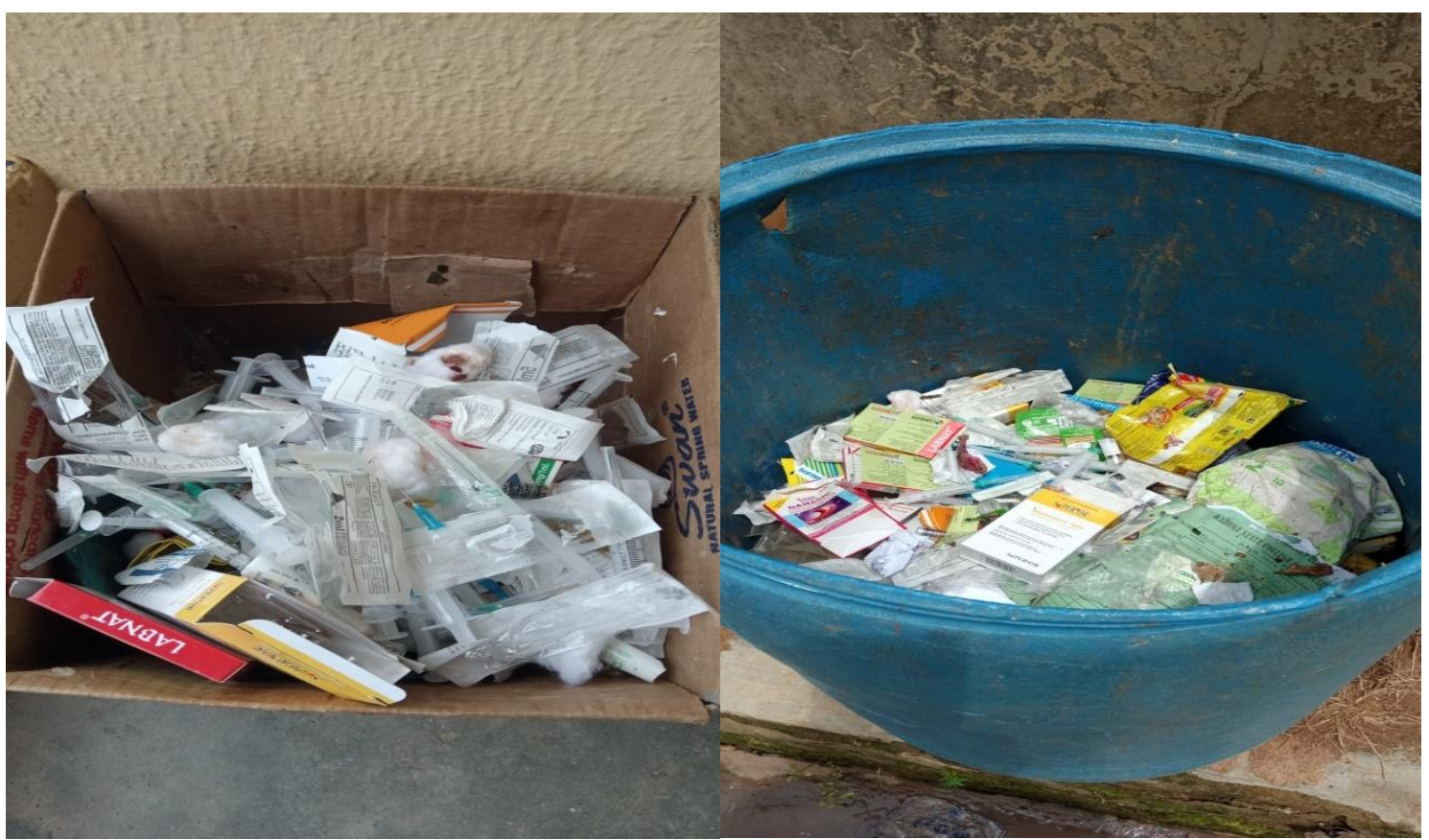

Plate 3: Unsecured Medical Wastes in a Box at a Medicine Store

Plate 4: Medical Wastes (syringes, used cotton wool) put in Household's Waste Bin

\section{Cutting of Trees for Fuel Purposes}

Another environmental effect of the COVID-19 is the indiscriminate cutting down of trees within residential areas and on the outskirts of the town for fuel purposes. Some have exploited the immediate surroundings and nearby reserved forests. The lockdown has resulted to loss of jobs, income and closure of businesses which placed them in difficult financial situations that some are unable to afford gas or kerosene to use as fuel for cooking purposes. The less privileged residents were left with little or no option than to cut down the trees for firewood which they have been using for cooking without recourse to the environmental effects such as intense heat, stronger greenhouse effects resulting to climate change, reduces absorption of contaminants, reduce provision of ecosystem service, affects hydrological cycle and depletion of medicinal and culinary trees as also reported by Mshelia et al. (2020).

\section{CONCLUSION AND RECOMMENDATIONS}

The study examined the environmental effects of COVID-19 in Kaduna metropolis with a view to educate the residents on the dangers associated with the lockdown and the need to adapt to the concept of environmental sustainability as well to key into the regulations, standards, policies and rules postulated by NESREA with respect to disposal and treatment of wastes especially wastewater and medical infectious waste. The study interviewed the residents of the metropolis and visited medical facilities and discovered that many people reported that the COVID-19 lockdown has led to less air pollution but increase in wastes generation as indicated by $86 \%$ and $50.5 \%$ respectively. This was because the residents sit at home with less to do, eat and the resultant effect is to frequently visit the toilet which in turn generates black wastewater. In the same vein, wastes management agencies hardly come by 
to collect the wastes generated at the dumpsites or in the dustbin as reported by $51.1 \%$ of the respondents. The study also discovered that some residents resorted to cutting down of trees in the community for fuel purposes to complement the inability to purchase gas or kerosene. Majority of the people with one ailment or the other patronize private and any medical points within their reach have resulted to generation of medical infectious waste in the communities. The issue discovered is that they do not treat these wastes in accordance to NESREA and environmental standard for the management of infectious wastes and this is a great threat to human health and the environment in general.

To mitigate the identified environmental problems the study recommends that:

a. Municipal solid wastes and medical infectious wastes should be properly stored in a secured container, treated and disposed in accordance to NESREA and environmental standards.

b. There should be constant supervision and monitoring of every part of the metropolis including the urban sprawls to ensure guidelines for disposal of wastes are adhered to.

c. Media public enlightenment among others to discourage the cutting down of trees that influences climate change in the community should be intensified.

d. Private hospitals, medical laboratories and other medical centres should always refer suspected cases of COVID-19 to isolation centres meant for treatment of such cases in the metropolis. 


\section{REFERENCE}

African Women Unite Against Destructive Resources Extraction (2020). Covid-19 Crisis upon Crisis in Africa: An Ecofeminist Perspective. 8 April 2020. https://roape.net/2020/03/31/pulverized- capitalism-africa-and-the-covid-19-crisis/

Al-Amin, M. A. and Dadan-Garba, A. (2014). Urban Vegetation Study of Kaduna Metropoli using GIS and remotely sensed Data. Journal of Natural Sciences Research www.iiste.org Vol.4 (2): 160-171.

Butu and Mshelia, (2017). Assessment of the Effectiveness of Municipal Solid Waste Management in Tarauni Local Government Area, Kano State, Nigeria.Development Journal of Science and Technology Research. Vol. 6 (2): 141 154

Bukky, S., Ariyo-Dare, A and Buky, W. (2020).Joint Memo by Civil Society Organizations on Response to COVID-19 Pandemic in Nigeria. https://nigeria.actionaid.org/news/2020/press-release-covid-19-publish-listpalliativebeneficiaries-anti-corruption-groups-urge

Calma J. (2020) The COVID-19 Pandemic is Generating Tons of Medical Waste. The Verge. (2020).

Cutler S. (2020). Mounting Medical Waste from COVID-19 Emphasizes the Need for a Sustainable Waste Management Strategy. Online blog. (2020).

Etukudoh, N. S., Ejinaka, R. O., Olowu, F. A., Obeta, M. U., Adebowale, O. M. And Udoudoh, M. P. (2020). Coronavirus ( COVID-19); Review from A Nigerian Perspective. American Journal of Biomedical Sciences and Research. Vol. 9(1): 26 35.

ESA, (2020).Coronavirus Lockdown leading to Drop in Pollution across Europe https://www.esa.int/Applications/Observing the_Earth/Copernicus/Sentinel5P/

Coronavirus. Accessed date: 4 April 2020

Goodland, R. (1995). The Concept of Environmental Sustainability. Annual Review of Ecological Systems 26 (1995): 1-24.

Mebratu, D. (1998). Sustainability and Sustainable Development: Historical and Conceptual Review. Environmental Impact Assessment Review 18 (1998): 493-520.

Mshelia, S. S., Mbaya, Y.A..and Emmanuel, G. (2020). Environmental Effects of Cutting Down of Urban Trees for Road Constructions in Kaduna Metropolis. International 
Journal of Advances in Engineering and Management. Volume 2 (1): 176-186. www.ijaem.net

Muhammad, F., Abdulkareem, J. H., \& Chowdhury, A. A. (2017). Major Public Health Problems in Nigeria: A Review. South East Asia Journal of Public Health, Vol. 7(1), 6-11.

Mustapha, M. (2011). Constraints of Waste Management in Kano Metropolis, Department of Economics, Bayero University Kano-Nigeria, Northern Nigeria,Vol.2. No.2.

NASA, (2020). https://earthobservatory.nasa.gov/images

NCDC, (2020). Covid-19 Update in Nigeria. 16/08/2020. Microsite, http://covid19.ncdc.gov.ng.

Nassiri, (2020).Perspective on Wuhan Viral Pneumonia. Advance in Public Health, Com and Trop Med: APCTM-106. Kosmos Publishers

National Environmental Standards and Regulations Enforcement Agency (NESREA). (2017)

NESREA, (2020). Guidelines for Handling Infectious Waste within the Context of Corona virus (Covid-19).)

Oruonye, E. D, and Ahmed, Y. M. (2020). Covid-19 and Challenges of Management of Infectious Medical Waste in Nigeria: A Case of Taraba State. International Journal Waste Resource, Vol. 10(3): 1-5

Roland R. (2020). Covid-19 and Challenges in the Provision of Solid Waste Services. (2020).

Tadama, H. M. (2016). Assessment of Municipal Solid Waste Management in Kaduna North Local Government Area, Kaduna State Nigeria. Un Published M.Sc Dissertation submitted to Geography Department, Postgraduate School, Nigerian Defence Academy Kaduna

UN Inter Agency Network on Youth Development (2020). Statement on Covid-19 and Youths https://www.youths@un.org

World Health Organisation, (2020a). Pneumonia of unknown cause - China

World Health Organization (2020d). Press Conference on Novel Coronavirus Outbreak. 